immune individuals. ${ }^{4}$ We have derived a formula that other institutions could use to determine $\mathrm{HBV}$ vaccination policies in their own settings.

\section{REFERENCES}

1. Dienstag JL, Ryan DM. Occupational exposure to hepatitis B virus in hospital person- nel: infection or immunization? $A m J$ Epidemiol 1982;115:26-39.

2. Centers for Disease Control. Recommendations of the Immunization Practices Advisory Committee. MMWR 1985;34::318-328.

3. Malik IA, Legters LJ, Luqman M. The etiological markers of hepatitis A and B in a healthy population in Southern Punjab. Journal of Pakistan Medical Association 1988;38:69-72.
4. Dienstag JL, Stevens CE, Bhan AK, Szmuness W. Hepatitis B vaccine administered to chronic cases of hepatitis B surface antigen. Ann Intern Med 1992;96:575-579.

Saeed Hamid, MRCP Ahmer Iqbal, MBBS, MBA The Aga Khan University Hospital Karachi, Pakistan

\title{
Request for Information on Application of Evidence-Based Medicine
}

\section{Murray D. Batt, MD}

"Currents," the news section of the Annals of Internal Medicine, is planning a story on evidence-based medicine and its practical application. They write “. . . we are hoping to spotlight some real-life examples of evidencebased medicine in action and its impact. If you are conducting research to evaluate the practical application of evidence-based medicine or if you have experience using evidence-based medicine principles in your daily work, ..." please contact Cori Vanchieri, news editor, Annals of Internal Medicine, 301589-5772 (e-mail_corivan@aol. com). 